\title{
Factors Affecting the Implementation of Active Learning Methods in Bale Zone Secondary Schools: Exploring Perceptions, Knowledge and Experiences of Students, Teachers and School Leadership
}

\author{
Baru Aboma Totoba \\ Department of Educational Planning and Management, Madda Walabu University, \\ Bale -Robe, Ethiopia \\ P.O.Box; +25122665247
}

\begin{abstract}
The purpose of this study was to explore factors that affecting the implementation of effective active learning method in Bale zone secondary schools' class. The total population of the study was 434 students from (grade $9^{\text {th }}$ and $\left.10^{\text {th }}\right) 60$ teachers teaching the grade $9^{\text {th }}$ and $10^{\text {th }}$ and 15 school leaders consisting, school principals, school instructional leaders and supervisors. The main instruments of data collection for this study were close ended questioners, focused interview and structured classroom observation check list. Then the data were gathered through these instruments and were presented, analyzed and interpreted by using a mixture of quantitative and qualitative data descriptive method using percentage in table and qualitative explanation. It has been seen from the study that the implementation of active learning methods was influenced by large class size, lack of resource, lack of commitment of teachers, misunderstanding as if student centered teaching is only grouping the students and providing tasks to be achieved which require large room for seating arrangement ineffective pedagogical center. Based on the finding of this study, the author has recommended the concerned body to give short term training for teachers in service about how to implement student centered method, building additional classroom to balance the number of students in a classroom, fulfilling different facilities and giving awareness for the students about the importance of active learning method in order to apply active learning method in their class at the secondary in this zone.
\end{abstract}

Keywords: Practices; Active Learning; Factors

DOI: $10.7176 /$ RHSS/11-1-05

Publication date: January $31^{\text {st }} 2021$

\section{Introduction}

Secondary school education is a tool in which students and youngsters get knowledge and experience about life. Students learn how to deal with problems, and apply their knowledge into real life problems. They improve their ability about logical thinking and reasoning, and get ready for their future. Active learning is, a learning process through which students become active participants in the learning process, is an important means for development of students 'skills. $\mathrm{nI}$ this process, students move from being passive recipients of knowledge to being participantin activities that encompass analysis, synthesis and evaluation besides developing skills, values and attitudes (Savin,et al.,2000).

In Ethiopia the current curriculum calls for emphasis on active learning and teaching approach and there for demand teachers to employ this teaching learning style. There is policy attention at national level and increasing demands for active learning and student-centered approaches to improve the quality of education and students' learning. However, little attempt is made by the policy document and other subsequent strategy documents to give due attention to it is implementation and facilitate condition enabling its utilization in teaching learning process at the class room situation. Under such circumstance different schools and teachers all followed their own way in translating active learning methods into practice

From his professional experience, informal observation and discussion with secondary school teachers, the researcher learned that implementation of Active Learning Methods in actual classroom teaching at Bale zone secondary schools appears very much limited. There is also a tendency to rely too much on the traditional methods and frequent resistance in employing the active learning methods on the part of teachers. Thu, active learning methods is commonly understood and used for what it is not. Education personnel at different levels are only phrasing around the term without mastering it and thereby providing support for teachers which is just only half the battle.

The problem may be attributed to lack of proper skills and learning experiences of teachers in the use of this teaching methods. It may also be lack of facilities enhancing active learning to the desired degree. There is also frequent resistance in employing Active Learning Methods on the part of teachers. In spite of all these challenges, few studies have been conducted to examine the practices of Active Learning Methods \& the major factors affecting its' employment in Bale Zone Secondary Schools. Thus, this study aimed to examine the practicality of 
Active Learning Methods and the Major factors affecting its' employment in Bale Zone senior Secondary School by answering raising the following basic Research questions: [1] Do teachers utilize Active Learning Methods in their classroom teaching in Bale Zone secondary schools? [2] What are the major factors hindering the application of Active Learning methods? [3] What are the possible way to overcome the factors hindering the use of Active Learning methods?

\section{Methodology}

In this study descriptive survey method was employed to address issues about the implementation of active learning Methods from the prospective of teaching strategies employed by teachers in Bale zone secondary schools. Descriptive Survey method is used describe the existing educational phenomena with the aim of justifying the current condition and practices in education. Therefore, this method was used for this study to describe and justify existing issues about the implementation of active learning methods from the prospective of teaching strategies employed by teachers in their classroom teaching in Bale zone secondary schools.

The source of data for this study were different group of respondents consisting of students and teachers, Principals, School unit Leaders and supervisors (schools' leaders) of Bale Zone Secondary School. Bale zone is dived in to twenty woredas each of them possessing one secondary school with exception that Sinana Woreda possessing two secondary (Galama and Robe secondary schools) teaching students of grade $9^{\text {th }}$ and $10^{\text {th }}$. From these twenty woredas $10(50 \%)$ of the total woredas were selected randomly to be included in this study. In this study both grade $9^{\text {th }}$ and $10^{\text {th }}$ were selected to fill questionnaire. A total of 434 students from both grade levels (9thand $10^{\text {th }} \mathrm{N}=226$ male and 208 female) students were included as a primary source of data for this study. In addition, about 60 teachers of which $\left(\mathrm{N}=12\right.$ female and $\left(\mathrm{N}=17\right.$ male) teachers teaching grade $9^{\text {th }}$ students and 31 , of which $\left(\mathrm{N}=16\right.$ male) and $\left(\mathrm{N}=14\right.$ female) teachers teaching grade $10^{\text {th }}$ were selected using stratified random sampling technique. A total of 15 School leaders consisting, $(\mathrm{N}=5$ Principals) and $(\mathrm{N}=5$ unit leaders $)$ and( $\mathrm{N}=5$ supervisors) were included in the study. Therefore, a total of 509 respondents were employed in this study as a primary source of data.

The major data collection instruments used for this study was questionnaire and interview. Self-administered Questionnaire was used to gather both qualitative and quantitative data. Thus, close ended questions with very limited number of open-ended items was employed for gathering information from all groups of respondents as they were relatively large in number. Thus, a total of 509 questionnaires set containing both open-ended and closeended items were prepared and distributed among respondents.

\section{Methods of Data Analysis}

In this study, both qualitative and quantitative data analysis methods were employed. The data collected through questionnaire were analyzed using the Statistical Package for Social Sciences computer software. The quantitative data were condensed into descriptive statistics like percentage, mean, chi-square. The qualitative data obtained through open-ended questionnaire, interview and documents were transcribed, and interpreted thematically. Analysis of qualitative data collected through interview were displayed first and then corroborated by qualitative data analysis in the form of texts and quotes.

\section{Result and Discussion.}

The practice of Active Learning Method in Bale Zone Secondary Schools

There is policy attention at national level and increasing demands for active learning methods to improve the quality of education and students' learning. However, the use of active Learning in classroom teaching at secondary schools was very much limited. Therefore, the following section aimed to address utilization of Active Learning methods. 
Table 2. The Implementation of Active Learning Method in Bale Zone Secondary Schools

\begin{tabular}{|c|c|c|c|c|c|c|c|c|c|c|}
\hline \multirow[t]{3}{*}{ No } & \multirow{3}{*}{$\begin{array}{l}\text { Item } \\
\text { Active Learning } \\
\text { methods }\end{array}$} & \multirow[t]{3}{*}{ Respondents } & \multicolumn{8}{|c|}{ Responses and frequency observed } \\
\hline & & & \multicolumn{2}{|c|}{ Always } & \multicolumn{2}{|c|}{ Sometimes } & \multicolumn{2}{|c|}{ Not at all } & \multicolumn{2}{|c|}{ Total } \\
\hline & & & $\mathrm{f}$ & $\%$ & $\mathrm{f}$ & $\%$ & $\mathrm{f}$ & $\%$ & Tot & $\%$ \\
\hline \multirow[t]{2}{*}{1} & \multirow[t]{2}{*}{ Retrieval practice } & Teachers & - & - & 20 & 33 & 40 & 67 & 60 & 100 \\
\hline & & Students & 84 & 19.3 & 140 & 32.22 & 210 & 48 & 434 & 100 \\
\hline \multirow[t]{2}{*}{2} & \multirow{2}{*}{$\begin{array}{l}\text { The } \\
\text { Procedure }\end{array}$} & Teachers & 13 & 21 & 7 & 1.16 & 40 & 67 & 60 & 100 \\
\hline & & Students & 50 & 11 & 100 & 23 & 288 & 63.33 & 434 & 100 \\
\hline \multirow[t]{2}{*}{3} & \multirow{2}{*}{ Role play } & Teachers & 13 & 21 & 35 & 58 & 12 & 20 & 60 & 100 \\
\hline & & Students & 120 & 27.6 & 92 & 21 & 222 & 51 & 434 & 100 \\
\hline \multirow[t]{2}{*}{4} & \multirow{2}{*}{ Think-pair-share } & Teachers & 17 & 28 & 16 & 26 & 27 & 45 & 60 & 100 \\
\hline & & Students & 142 & 33 & 22 & 5 & 270 & 62.2 & 434 & 100 \\
\hline \multirow[t]{2}{*}{5} & \multirow{2}{*}{ Minute papers } & Teachers & - & & 9 & 15 & 51 & 85 & 60 & 100 \\
\hline & & Students & 34 & 7.8 & 152 & 35 & 248 & 57 & 434 & 100 \\
\hline \multirow[t]{2}{*}{6} & \multirow{2}{*}{ Strip sequence } & Teachers & - & & 3 & 5 & 57 & 95 & 60 & 100 \\
\hline & & Students & 5 & 1.15 & 182 & 42 & 246 & 57 & 434 & 100 \\
\hline \multirow[t]{2}{*}{7} & \multirow{2}{*}{$\begin{array}{l}\text { Case-based } \\
\text { learning }\end{array}$} & Teachers & 16 & 26 & 11 & 18 & 33 & 55 & 60 & 100 \\
\hline & & Students & 60 & 14 & 84 & 19.35 & 290 & 44 & 434 & 100 \\
\hline \multirow[t]{2}{*}{9} & \multirow[t]{2}{*}{ Demonstration } & Teacher & - & - & 40 & 67 & 20 & 33 & 60 & 100 \\
\hline & & Students & 50 & 11 & 320 & 72 & 60 & 13.8 & 434 & 100 \\
\hline \multicolumn{3}{|c|}{ Average mean } & 1.1 & & 2.4 & & 4.1 & & & \\
\hline
\end{tabular}

The table above table 2 present respondent view on implementation of different active learning methods in the classroom teaching at some selected Bale zone secondary. For this purpose, the respondents Teachers and students were given three scales as always, sometimes and not at all to see how often different active learning methods are employed by teachers in their classroom teaching.

According to. (Brame and Biel, 2015) Retrieval practice which is practiced by Pause for two or three minutes every 15 minutes, having students write everything they can remember from preceding class segment to Encourage questions. This active learning method was used not used at all in the classroom teaching as majority (67\%) of students and (48\%) of the teachers. replied that Retrieval practice was sometimes used by in the classroom teaching for $(33 \%)$ of the teachers and $(32.22 \%)$ in the classroom teaching at their school. In the pause procedure teachers Pause teaching for two minutes every 12 to 18 minutes, encouraging students to discuss and rework notes in pairs was utilized a sometime in their classroom while role play was sometimes used in the teaching. Concerning utilization this method in teaching learning, majority (67\%) of teachers and (63.33\%) of the students of the students replied, it was not used at all in their classroom teaching. Role play was not used in the classroom in teaching Learning at Bale zone secondary schools for $(20 \%)$ the teachers and $(51 \%)$ the teachers' respondent while it was sometimes used in the classroom teaching for $(58 \%)$ of the teachers and $(21 \%)$ of the students' respondents. In think-pair-shar teacher ask students to think or write about an answer for one minute, then turn to a peer to discuss their responses for two minutes. Ask groups to share responses and follow up with instructor explanation. Thinkpair-share was not used as teaching method according to (45\%) of the teachers and $(67 \%)$ of students' respondents. Minute papers was among the methods sometimes used by teachers in the classroom teaching at Bale Zone Secondary schools as the responses of $(85 \%)$ of the teachers and $(57 \%)$ of the students. Sometime project is used as method of teaching as indicated by $(55 \%)$ of the teachers and $(66.82 \%)$ of the students. According to (Handelsman et al., 2007), Strip sequence practiced by giving students the steps in a process on strips of paper that are jumbled; ask them to work together to reconstruct the proper sequence. This approach can strengthen students' logical thinking processes and test their mental model of a process. (. This teaching method was the teaching methods which was not utilized by most of the teachers in the secondary schools under this study as viewed by the almost all (95\%) of the teachers and majority $(57) \%$ of the students.

According to the majority of teachers (55\%) of teachers and (44\%) of students respondents Case based learning was not employed in teaching learning at Bale zone secondary schools. In this method we provide students with a case, asking them to decide what they know that is relevant to the case, what other information they may need, and what impact their decisions may have, considering the broader implications of their decisions. Provide opportunities for groups to share responses; the greatest value from case-based learning comes from the complexity and variety of answers that may be generated. In the teaching learning at Bale zone secondary schools Demonstration was the only active learning method always employed by teachers as majority (72\%) of the teachers and $(67 \%)$ of the students responses. In this method we ask students to predict the result of a demonstration, briefly discussing with a neighbor. After demonstration, ask them to discuss the observed result and how it may have differed from their prediction; follow up with instructor explanation. Generally, the table 2 above, shown 
Active learning methods was not frequently used teachers in their teaching at some selected Bale zone Secondary schools. The mean average ( $\mathrm{X}^{-}=1.1$. for active learning $\mathrm{s}$ always used, $)\left(\mathrm{X}^{-}=2.4\right.$ for active learning sometimes used )and $\left(\mathrm{X}^{-}=4.1\right.$ for active learning not used at all). There is no difference in the response of both group of students and teachers' respondents. Teachers are not $\mathrm{n}$ translating active learning methods into practice. This means active learning methods are utilized rarely at Bale school secondary schools. This show that teachers dominated teaching method class in which the students are passive participants of teaching learning is dominating teaching learning process at these schools.

\section{2. The major factors hindering the application of Active Learning methods} Table 2. Teachers knowledge of Active Learning methods and its utilization

\section{No}

1 Have you ever received training on active learning teaching approach?

2 If you have received training on active learning teaching approach? did it help you to understand \& utilize it in your class room instruction?

4 Have you ever followed workshop / higher diploma on active learning?

5 Do you think training will increase your knowledge about on active learning teaching approach?

6 Do think student centered teaching approach is only about grouping the students \& providing tasks?

Mean

One of the factors hindering the affect effective implementation Active learning teaching is teachers 'knowledge. This is also the case for Bale zone senior secondary school teachers where (67\%) of the teachers' respondents replied as they haven't received training on how to exercise active learner. It also requires preparing workshop to renew teacher's knowledge and increase teacher's awareness for effective utilization of active learning. Asked if they believe that training on active learning methods improve their practice of the methods in open ended questionnaire majority of the respondents told that they belief such training program could increases their knowledge of active learning methods and described that they needed it.

School supervisors were asked in interview to talk to teacher's knowledge of active learning methods as a challenge that affect the utilization of their schools and they told that active learning knowledge gap was manifested in their schools.

Their interview result has transcribed as follows:

"Misunderstanding, 'wrong believe that active learning causes too much noise', 'constantly focus on theoretical knowledge, instead of practical application', 'show resistance and considering the change as political (feeling ashamed to follow the reform, they do what they have been accustomed to do)', and 'focus only on students' academic success

Hence, it could be concluded most teachers teaching in the schools under study have understood active learning for what it is not. Therefore, it is better to give training to improve attitudes and increase knowledge of most teachers teaching in the secondary schools of Bale zone. 
Table .2 Teachers Perception and its utilization of Active Learning Methods

\begin{tabular}{|c|c|c|c|c|c|c|c|c|c|}
\hline \multirow{3}{*}{ Item } & \multirow[t]{3}{*}{ Variables } & & & & \multicolumn{3}{|c|}{ Respondents } & \multirow[t]{3}{*}{ Tot } & \multirow[t]{3}{*}{$\chi 2$ \& P-value } \\
\hline & & \multicolumn{2}{|c|}{ Teachers } & \multicolumn{2}{|c|}{ Students } & \multicolumn{2}{|c|}{$\begin{array}{l}\text { School } \\
\text { managers }\end{array}$} & & \\
\hline & & $\mathrm{N}$ & $\%$ & No & $\%$ & No & $\%$ & & \\
\hline \multirow{12}{*}{$\begin{array}{l}\text { The lecture method } \\
\text { teaching strategy is } \\
\text { more suited to the } \\
\text { current curriculum } \\
\text { \&students } \\
\text { background } \\
\text { Active learning is } \\
\text { only about grouping } \\
\text { the students \& } \\
\text { providing tasks }\end{array}$} & Strongly Agree & 50 & 38.33 & 129 & 29.26 & 11 & 19.64 & 133 & \multirow{6}{*}{$\begin{array}{l}\chi^{2}=39.239 \\
P=.000 \\
D f=4\end{array}$} \\
\hline & Agree & 8 & 13.33 & 72 & 16.58 & 3 & 30.35 & 138 & \\
\hline & Not sure & 21 & 35.00 & 95 & 21.88 & - & & 116 & \\
\hline & Strongly Disagree & 5 & 8.33 & 44 & 10.13 & - & & 49 & \\
\hline & Total & 60 & & 434 & & 15 & 100 & 509 & \\
\hline & Strongly Agree & 17 & 28.33 & 136 & 31.33 & 10 & 12.50 & 101 & \\
\hline & Agree & 10 & 16.66 & 97 & 22.35 & 3 & 30.35 & 117 & \multirow{6}{*}{$\begin{array}{l}\chi^{2}=9.142 \\
\mathrm{P}=.330\end{array}$} \\
\hline & Not sure & 13 & 21.66 & 18 & 18.66 & 2 & 33.92 & 151 & \\
\hline & Disagree & 14 & 23.33 & 61 & 14.05 & - & & 75 & \\
\hline & Strongly Disagree & 6 & 10.00 & 59 & 13.59 & - & & 65 & \\
\hline & Total & 60 & & 434 & & 15 & 100 & 509 & \\
\hline & Strongly Agree & 20 & 33.33 & 106 & 24.42 & 12 & 8.92 & 87 & \\
\hline \multirow{12}{*}{$\begin{array}{l}\text { Students' role is } \\
\text { listening lecture, } \\
\text { note taking \& } \\
\text { response to question } \\
\text { upon request } \\
\text { Teaching is the sole } \\
\text { responsibility of } \\
\text { teacher }\end{array}$} & Agree & 19 & 31.66 & 52 & 11.98 & 2 & 37.50 & 73 & \multirow{7}{*}{$\begin{array}{l}\chi^{2}=49.83 \\
\mathrm{P}=.000 \\
\mathrm{Df}=8 \\
\chi^{2}=14.742 \\
\mathrm{P}=.064\end{array}$} \\
\hline & Not sure & 3 & 5 & 82 & 18.89 & 1 & 26.78 & 127 & \\
\hline & Disagree & 13 & 21.66 & 91 & 20.96 & \multirow{2}{*}{\multicolumn{2}{|c|}{-}} & 104 & \\
\hline & Strongly Disagree & 5 & 8.33 & 103 & 23.73 & & & 108 & \\
\hline & Total & 60 & & 434 & & 15 & 100 & 509 & \\
\hline & & & & & & & & & \\
\hline & Strongly Agree & 17 & 28.33 & 136 & 31,33 & 13 & 12.50 & 104 & \\
\hline & Agree & 10 & 16.68 & 97 & 22.35 & 1 & 30.35 & 115 & \\
\hline & Not sure & 13 & 21.66 & 82 & 18.66 & 1 & 33.92 & 150 & \\
\hline & Disagree & 14 & 23.33 & 61 & 14.05 & & & 75 & \\
\hline & Strongly Disagree & 6 & 10.00 & 59 & 13.59 & & & 65 & \\
\hline & Total & 60 & & 434 & & 15 & & 509 & \\
\hline \multirow{7}{*}{$\begin{array}{l}\text { Understanding is a } \\
\text { long process that } \\
\text { can achieved } \\
\text { through repetition \& } \\
\text { drill }\end{array}$} & & 50 & 38.33 & 72 & 16.58 & 14 & 19.64 & 136 & \multirow{6}{*}{$\begin{array}{l}\chi^{2}=37.405 \\
P=.000\end{array}$} \\
\hline & Strongly Agree & & & & & & & & \\
\hline & Agree & 21 & 35 & 127 & 29.26 & 1 & 30.35 & 136 & \\
\hline & Not sure & 8 & 13.33 & 95 & 21.88 & & & 116 & \\
\hline & Disagree & 5 & 8.33 & 44 & 10.13 & & & 49 & \\
\hline & Strongly Disagree & 60 & & 434 & & 15 & 100 & 509 & \\
\hline & Total & & & & & & & & \\
\hline \multirow{7}{*}{$\begin{array}{l}\text { teachers must use } \\
\text { lecture method if } \\
\text { they are more } \\
\text { familiar with it }\end{array}$} & & & & & & & & & \\
\hline & Strongly Agree & 20 & 5.00 & 82 & 18.89 & 9 & 8.92 & 94 & \multirow{6}{*}{$\begin{array}{l}\chi^{2}=49.83 \\
\mathrm{P}=.000\end{array}$} \\
\hline & Agree & 19 & 31.66 & 52 & 11.98 & 4 & 37.50 & 75 & \\
\hline & Not sure & 3 & 5 & 106 & 24.42 & 2 & 26.78 & 128 & \\
\hline & Disagree & 13 & 21.66 & 91 & 20.96 & & 19.64 & 104 & \\
\hline & Strongly Disagree & 5 & 8.33 & 103 & 23.73 & & 7.14 & 108 & \\
\hline & Total & 60 & & 434 & & 15 & & 509 & \\
\hline \multirow{7}{*}{$\begin{array}{l}\text { Teachers should use } \\
\text { lecture methods } \\
\text { since Students are } \\
\text { happy with it }\end{array}$} & & & & & & & & & \multirow{7}{*}{$\begin{array}{l}\chi^{2}=37.405 \\
P=.000\end{array}$} \\
\hline & Strongly Agree & 23 & 38.33 & 96 & 22.11 & 12 & 10.71 & 111 & \\
\hline & Agree & 8 & 13.33 & 72 & 16.58 & 2 & 19.64 & 97 & \\
\hline & Not sure & 3 & 5 & 127 & 29.26 & 2 & 30.35 & 137 & \\
\hline & Disagree & 21 & 35.00 & 95 & 21.88 & & & 116 & \\
\hline & Strongly Disagree & 5 & 8.33 & 44 & 10.13 & & & 49 & \\
\hline & Total & 60 & & 434 & & 15 & 100 & 509 & \\
\hline
\end{tabular}

Table 3 above present that Bale zone Secondary School teachers misunderstood active learning methods as most of $(38.33 \%)$ of the teachers, $(16.58 \%)$ of the students and $(19.64 \%)$ of the school managers strongly agreed that lecture method teaching strategy is more suited to the current curriculum and students background. The observed, $\chi^{2}=13.332$ with $\mathrm{df}=8$, at calculated value of $\mathrm{P}=.101$ at $\alpha=.05$ level of significance, no significant difference was observed between the teachers, students and schools' mangers responses.

Active Learning Methods is not only grouping learners in the class and provide tasks, however there are 
different techniques to be used like question answer, quizzes, individual activity. This was not the case in Bale zone Senior Secondary school where majority (57\%) of the teacher respondents replied they expect active learning teaching approach is only grouping learners in the class and giving tasks to achieve, tasks. However, active learning is more than grouping the students and providing tasks while the others $(43.33 \%)$ know the other technique.

In the table 3 above $(20 \%)$ teachers, $(19.81 \%)$ of students and $(7.14 \%)$ of school managers strongly agreed and $13(21.66 \%)$ of teachers, $93(21.42 \%)$ of students and $7(12.50 \%)$ of school managers agreed that Students' role is listening lecture, note taking and response to question upon. The chi-square results were, $\chi^{2}=150.124$, with $\mathrm{df}=8 \mathrm{P}=.000$ shows that at $\alpha=.05$ level of significance, indicate that there is a significant difference between the responses of the teachers, students and school mangers in their responses on this item.

The table above shows that $(13.33 \%)$ of teachers $(21.19 \%)$ of students and $(1.78 \%)$ of school managers 'strongly agree' and $(6.66 \%)$ of teachers, $(21.88 \%)$ of students and $(14.28 \%)$ of school mangers 'agree' that the modes of the teaching are most of the time lecture dominated. On the other hand, 18(30) of teachers, 130(29.95) of students and $21(37.50 \%)$ of school managers uncertain and $17(28.33 \%)$ of teachers, $93(21.42 \%)$ of students and $15(26.78 \%)$ of school managers disagree were responded respectively regarding this issue. The calculated results of $\chi^{2}=44.972$, with $\mathrm{df}=8$, at $\mathrm{P}=.000$, at $\alpha=.05$ level of significance. Statistically there is a significant difference between the responses of teachers, students and school managers. From the data majority of the respondents indicated uncertainty. This shows the provision of the courses are most of the time lecture methods. The problem of knowledge gap was manifested where most teachers has understood this approach (active learning methods) for what it is not. Therefore, it is better to give training to increase their understanding. Teachers' implementation of Active Learning could be affected by their beliefs about effective practices.

In order for Active Learning to be used as intended, designers must be aware of the key issues that will shape their implementation and the beliefs teachers hold about these issues. The failure or success of any instructional approach ultimately depends on attitude, values, skills and knowledge of classroom teachers. Therefore, it needs training to improve teachers' skills and attitudes towards active learning method to enhance its practices at this secondary schools of this zone. 
Table 3. Teachers and students' response on active learning and Resource Requirement in Bale zone senior secondary school

NO. ITEMS

VARIABLES

\section{RESPONDENTS}

Students

Teachers

No $\% \quad$ No $\%$

1

$\begin{array}{lrr}\text { Class } & \text { room Adequate } \\ \text { setup } & \text { is } & \text { Moderate }\end{array}$

conducive to Not at all

carrying out

active learning

2

Learning

resource

adequate

concrete

employing

active learning

3

Class size and

seating

arrangement is

appropriate for

carrying out

active learning

4

There pedagogical

centre

is

is

Strongly agree

somewhat

Not at All

Total

encourage active

learning

5

Charts/diagrams

6

7

Other

Equipment

7

Different

Models

8

Maps

$9 \mathrm{Comp} / \mathrm{LCD} /$

Text books
Strongly Agree

Somewhat

\section{Strongly Agree}

Somewhat

Not at all

Not at all

St

Somewhat

Not at all

Total

Adequately available

Moderately available

Inadequately available

Total

Adequately available

Moderately available

Inadequately available

Total

Adequately available

Moderately available

Inadequately available

Total

Adequately available

Moderately available

Inadequately available

Total

Adequately available

Moderately available

Inadequately available

Total

Adequately available

Moderately available

Inadequately available $\begin{array}{llll}13 & 21.66 & 200 & 46.08\end{array}$

$\begin{array}{lllll}2 & 3.33 & 15 & 3.45 & 17\end{array}$

$\begin{array}{lllll}2 & 3.33 & 22 & 5.06 & 24\end{array}$

$\begin{array}{lllll}3 & 5.0 & 15 & 3.45 & 18\end{array}$

$\begin{array}{lllll}5 & 8.33 & 91 & 20.96 & 96 \\ 5 & 8.33 & 91 & 20.96 & 96 \\ 55 & 91.66 & 343 & 79.02 & 398\end{array}$

$\begin{array}{lllll}- & - & 4 & 0.92 & 4\end{array}$

$\begin{array}{llllll}45 & 75.0 & 219 & 50.46 & 264\end{array}$

$\begin{array}{lll}60 & 434\end{array}$

TOTAL $\mathbf{X}^{2}$

P-

VALUE

$\begin{array}{lllll}13 & 21.66 & 150 & 34.56 & 163\end{array}$

$\begin{array}{lllll}45 & 74.99 & 262 & 60.36 & 307\end{array}$

$\begin{array}{lll}60 & 434\end{array}$

4.799

.091

$13.230 \quad .001$

$\begin{array}{lllll}17 & 28.33 & 121 & 27.88 & 138\end{array}$

$\begin{array}{lllll}40 & 66.66 & 298 & 68.66 & 338\end{array}$

$\begin{array}{lll}60 & 434 & 494\end{array}$

$2.332 \quad .506$

$\begin{array}{lllll}5 & 8.33 & 91 & 20.96 & 96\end{array}$

$\begin{array}{lllll}55 & 91.66 & 343 & 79.02 & 398\end{array}$

$\begin{array}{lll}60 & 434\end{array}$

$\begin{array}{lllll}55 & 91.66 & 343 & 79.02 & 398\end{array}$

$\begin{array}{lll}60 & 434 & 494\end{array}$

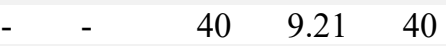

$\begin{array}{lllll}12 & 20.0 & 267 & 61.52 & 279\end{array}$

$59.927 \quad .000$

$\begin{array}{lllll}48 & 79.99 & 127 & 29.25 & 175\end{array}$

$\begin{array}{lll}60 & 434 & 494\end{array}$

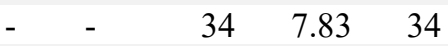

$\begin{array}{lllll}13 & 21.66 & 125 & 28.80 & 138\end{array}$

7.473

.024

$\begin{array}{lllll}47 & 78.33 & 275 & 63.36 & 322\end{array}$

$\begin{array}{lll}60 & 434 & 494\end{array}$

$\begin{array}{lllll}1 & 1.66 & 5 & 1.15 & 6\end{array}$

$\begin{array}{lllll}5 & 8.33 & 133 & 30.64 & 138\end{array}$

$13.043 \quad .001$

$\begin{array}{lllll}54 & 90.00 & 296 & 68.02 & 350\end{array}$

$\begin{array}{lll}60 & 434 & 494\end{array}$

$\begin{array}{lllll}16 & 26.66 & 144 & 33.17 & 160\end{array}$

1.680

.432

$\begin{array}{lllll}44 & 73.33 & 286 & 65.89 & 330\end{array}$

$\begin{array}{lll}60 & 434 & 494\end{array}$

$\begin{array}{lllll}6 & 10.0 & 56 & 12.90 & 62\end{array}$

$\begin{array}{lllll}6 & 10.0 & 56 & 12.90 & 62 \\ 13 & 68.33 & 232 & 53.45 & 273\end{array}$

$\begin{array}{lllll}13 & 21.66 & 146 & 33.63 & 169\end{array}$

$\begin{array}{llll}60 & 434 & 494\end{array}$

$4.813 \quad .090$

$\begin{array}{lllll}55 & 91.66 & 343 & 79.02 & 398\end{array}$

$\begin{array}{lllll}60 & 434 & 494\end{array}$

$\mathrm{Df}=2$

5.759

.056

$\begin{array}{llll}8.33 & 91 & 20.96 \quad 96\end{array}$

The availability and quality of teaching materials strongly affect what teacher can do. The application of active learning should not be the sole responsibility of the individual teacher. Change in teaching learning method 
is likely to mean that the institution's resources facility will become more important for the employment of active learning. Teachers are often teaching in a situation where other factors do not influence. Being a good teacher is sometimes a matter of being allowed to be good teacher. Creative and innovative teaching does not flourish in a vacuum. The classroom starts becoming learner centered and takes on different feeling when learners were provided with appropriate resources supports. The condition of school facilities has a measurable effect over and above socioeconomic conditions on student achievement and teacher experience/turnover.

The table shown that $(75 \%)$ teachers and $(50.49 \%)$ students responded that text books are moderately available. In their schools. The chi-square value $\chi^{2}=13.230, \mathrm{P}=.001$ shows with $\mathrm{df}=2$ when $\alpha=0.05$ level there is significant difference in the response between teachers and students for this item. The teachers denoted more than the students. During observation, it was confirmed that the inadequacy of text books is not serious. Regarding the reference materials, majority of the respondents, $45(74.99 \%)$ students and $262(60.36 \%)$ students, indicated that reference books are inadequately available. The chi-square test results $\chi^{2}=4.799$, with $\mathrm{df}=2$, at $\mathrm{p}=.091$, at $\alpha=$ 0.05 significance level, implies that there is no significant difference between the responses of teacher and students on the availability of reference books. This was confirmed when library was observed for the study.

Regarding short note majority $(66.66 \%)$ of the teachers and $(68.66 \%)$ of students indicated that handouts are inadequate. Observed, $\chi^{2}=2.332$, with $\mathrm{df}=2$ at value of $\mathrm{P}=.506$ at $\alpha=0.05$ significance level there is no significant difference between the responses of teachers and students. This indicates that there is a shortage of short notes as one the teaching input. With regard to the availability of charts/diagrams for students, majority of the respondents $(91.66 \%)$ of teachers' and $(79.02 \%)$ of students responded it was inadequate. The p- value with $\mathrm{df}=2$ at $\alpha=0.05$ significance level, $\chi^{2}=5.759, p=.056$ it implies that there is no significant difference between the responses of teacher teachers and students. This was also proved by using observation check list that, charts/diagrams are inadequate for teaching in most of the secondary schools under study.

Regarding laboratory chemicals majority $(79.99 \%)$ of teachers indicated that chemicals are inadequate and $(61.52$. \%) of students indicated that availability of chemicals in Bale Zone Senior Secondary Schools was moderate. Statistically significance difference among the teachers and students' response was observed $\left(\chi^{2}=59.92\right.$ with $\mathrm{df}=2, \mathrm{p}=0.000$ ). In order to crosscheck students response with regard to the availability of chemicals physical observation was made and approved chemicals that there were there some chemicals in the laboratory as indicated by the teachers respondents.

Regarding equipment $(21.66 \%)$ of the teachers and $(28.8 \%)$ of students responded equipment were moderately available. On the other hand, most of the respondents $(90 \%)$ of teachers and $(68.02 \%)$ of students responded that, equipment for science subjects training were inadequate and this was confirmed through observation. Concerning model is concerned, majority $(85 \%)$ of teachers and $(50.69 \%)$ of students indicated that different models for students were less in their school. Concerning the availability of maps $(73.33 \%)$ of teachers and $286(65 \%)$ of students indicated the available map were inadequate while it was moderate for $(26.66 \%)$ of teachers and $(33.17 \%)$ of students. The chi-square results for most of the items shows that at $\alpha=0.05$ level of significance, there was no statistically significant difference between the respondent responses on the availability of material inputs in Bale Zone Secondary Schools. since the p-value is greater than .05. Therefore, it could be concluded that most of the inputs are not adequate in the secondary schools under study. Thus, this prevailing factor affecting the implementation of active learning in the Secondary Schools of Bale zone teaching was shortage of teaching materials. Teshome (2004) also indicated that if the availability of libraries, laboratories and classrooms are below the minimum requirement that can affect educational quality. The information obtained from, that majority the respondents, teachers', students and school managers indicated that the school situations and classroom arrangements were not conductive to implement the active learning approach. To check this responses interview has made with teachers and presented as hereunder:

Front back seating arrangements encourages only one-way communication. It was difficult to talk to the back of someone else's head. This made the students silent listeners of their instructors.

Teachers also complained about the large class size teachers replied that in a classroom about 60 or more students, only very small proportion of the students respond to question even they were fast learners only. Furthermore, the majority of teachers told that they were constrained by lack of adequate resource for using active learning approach. The only available teaching aids were used only by teachers/ As shown in the literature part of this study change in teaching learning method is likely to mean that the institution's resources facility will become more important for the employment of active learning. Teachers are often teaching in a situation where other factors do not influence.

The result of classrooms observation shown that most classroom of the secondary schools of the zone was overcrowded accommodating averagely between $61-70$ students in per-classrooms. As $63.4 \%$ of teachers', $51.2 \%$ of students' and $80 \%$ of supervisors' respondents reported that classrooms are not appropriate for teaching and learning. The information obtained from open-ended question was possibly associated with large classroom size, lack of commitment on the part of teachers, lack of adequate resources, in effectiveness of pedagogic center. In 
this study the adequacy and accessibility of material inputs as important elements for teaching in Bale Zone Senior Secondary school were considered and assessed using rating variables (adequately, moderately and inadequately available). As it was stated by Rob (1996), input indicator measures the means or the resources employed to facilitate quality training. The materials need to be designed for use in the context of a class organized along active learning lines. They need to consist carefully sequenced sets of guiding activities designed for learners and should be intended to be used actively by students. Therefore, it can be concluded that the situation and classroom arrangements of the schools was among the factors affecting the implementation of Active learning approach in teaching in the secondary schools of the zone. Hence it is reasonable if the concerning body provide the necessary situation and motivate the creative abilities of teachers and students.

\begin{tabular}{|c|c|c|c|c|c|c|c|c|c|c|}
\hline \multirow[t]{3}{*}{ NO } & \multirow[t]{3}{*}{ ITEM } & \multirow[t]{3}{*}{ VARIABLES } & \multicolumn{6}{|c|}{ RESPONDENTS } & \multirow[t]{3}{*}{ TOT } & \multirow{3}{*}{$\begin{array}{l}\mathrm{X}^{2} \\
\text { AND P- } \\
\text { VALUE }\end{array}$} \\
\hline & & & \multicolumn{2}{|c|}{ Teachers } & \multicolumn{2}{|c|}{ Students } & \multicolumn{2}{|c|}{$\begin{array}{l}\text { School } \\
\text { manager }\end{array}$} & & \\
\hline & & & No & $\%$ & No & $\%$ & No & $\%$ & & \\
\hline \multirow[t]{6}{*}{1.} & The components of & SA & 27 & 45.00 & 163 & 37.55 & 19 & 33.92 & 209 & \multirow{6}{*}{$\begin{array}{l}\chi^{2} \\
=13.332 \\
\mathrm{P}=.101\end{array}$} \\
\hline & the courses provided & A & 17 & 28.33 & 138 & 31.79 & 17 & 30.35 & 172 & \\
\hline & are more theoretical & UN & 8 & 13.33 & 103 & 23.73 & 9 & 16.07 & 120 & \\
\hline & & $\mathrm{D}$ & 6 & 10.00 & 16 & 3.68 & 6 & 10.71 & 28 & \\
\hline & & SD & 2 & 3.33 & 14 & 3.22 & 5 & 8.92 & 21 & \\
\hline & & Tot & 60 & & 434 & & 56 & & 550 & \\
\hline \multirow[t]{6}{*}{2.} & The duration of time & SA & 12 & 20.00 & 86 & 19.81 & 4 & 7.14 & 102 & \multirow{6}{*}{$\begin{array}{l}\chi^{2} \\
=150.124 \\
\mathrm{P}=.000\end{array}$} \\
\hline & allotted for each & A & 13 & 21.66 & 93 & 21.42 & 7 & 12.50 & 113 & \\
\hline & course is insufficient & UN & 5 & 8.33 & 105 & 24.19 & 13 & 23.21 & 123 & \\
\hline & & $\mathrm{D}$ & 21 & 35.00 & 90 & 20.73 & 32 & 57.14 & 143 & \\
\hline & & SD & 9 & 15.00 & 60 & 13.82 & - & - & 69 & \\
\hline & & Tot & 60 & & 434 & & 56 & & 550 & \\
\hline \multirow[t]{6}{*}{3} & $\begin{array}{l}\text { The modes of delivery } \\
\text { of the courses } \\
\text { designed in the }\end{array}$ & SA & 8 & 13.33 & 92 & 21.19 & 1 & 1.78 & 101 & \multirow{6}{*}{$\begin{array}{l}\chi^{2} \\
=44.970 \\
P=.00 \\
0\end{array}$} \\
\hline & textbooks suiting & A & 4 & 6.66 & 95 & 21.88 & 8 & 14.28 & 107 & \\
\hline & lecture methods more & UN & 18 & 30.00 & 130 & 29.95 & 21 & 37.50 & 169 & \\
\hline & & $\mathrm{D}$ & 17 & 28.33 & 93 & 21.42 & 15 & 26.78 & 125 & \\
\hline & & SD & 13 & 21.66 & 24 & 5.52 & 11 & 19.64 & 48 & \\
\hline & & Tot & 60 & & 434 & & 56 & & 550 & \\
\hline
\end{tabular}

\section{$\mathbf{D f}=\mathbf{8}$}

In order to assess Curriculum Contents and the Employment of Active Learning Methods, respondents consisting teachers, students and school managers were given alternative response from strongly agree to strongly disagree if the curriculum content of their school hinder the implementation of active learning methods in their classroom. Therefore, the table 5 above show the respondents view on the issues like the components of the courses provided are more theoretical, the duration of time allotted for each course is insufficient and the modes delivery designed for the courses is more of lecture methods.

Accordingly, most of the Teachers (45\%), students (37.55\%) and (33.92\%) school managers strongly agreed, that the components of the courses delivered in their secondary school was are more theoretical while some of the respondents agreed that the components of the courses provided are more theoretical. The observed, $\chi^{2}=13.332$ with $\mathrm{df}=8$, at calculated value of $\mathrm{P}=.101$ at $\alpha=.05$ level of significance, no significant difference was observed between the teachers, students and school managers.

Concerning the course contents and the time allotted about $(20 \%)$ of teachers, $(19.81 \%)$ of students and (7.14\%) of school managers strongly agreed and $(21.66 \%)$ of teachers, $(21.42 \%)$ of students and $(12.50 \%)$ of school mangers agreed. while, $(8.33 \%)$ of teachers, $1(24.19 \%)$ of students and $13(23.21 \%)$ of school managers were uncertain. The chi-square results were, $\chi^{2}=150.124$, with $\mathrm{df}=8 \mathrm{P}=.000$ shows that at $\alpha=.05$ level of significance, indicate that there is a significant difference between the responses of the teachers, students and school managers in their responses for this item. The data shows majority of the teachers, students and school managers disagree with the idea that duration of learning/training hours is insufficient.

For $(13.33 \%)$ of teachers $(21.19 \%)$ of students and1(1.78\%) of school managers 'strongly agree' and $(6.66 \%)$ of teachers, $(21.88 \%)$ of students and $8(14.28 \%)$ of school managers 'agree that course delivery designed are suited 
of lecture. On the other hand, (30) of teachers (29.95) of students and (37.50\%) of school managers were uncertain and $(28.33 \%)$ of teachers, $9(21.42 \%)$ of students and $15(26.78 \%)$ of managers disagree were responded respectively. The calculated results of $\chi^{2}=44.972$, with $\mathrm{df}=8$, at $\mathrm{P}=.000$, at $\alpha=.05$ level of significance. Statistically there is a significant difference between the responses of teachers, students and school managers. the courses delivery methods designed in the textbook contents were more suited with lecture. the major factor that mainly influences the implementation of active learning approach were the availability of text books, teacher's guides and different reference books in their school library. Asked the situation at their schools, teachers stated as follows:

\begin{abstract}
“"number of students' in per-classroom, lack of resources and lack of students' interest to learn through Active learning approach". Majority of the school leaders were assigned to the schools without any training and it resulted in the retardation of the required active learning approach. All of the school supervisors were agreeing that there were supervision activities in the school more than two times in a year and $100 \%$ of them were also agree that teachers were well aware about active learning approach. Majority of the school supervisors were indicated that teachers had positive attitudes towards the implementation of the curriculum using active learning approach.
\end{abstract}

The specific obstacles associated with active learning included the following: limited class time, the density of the curriculum, the potential difficulty of using active learning in large classes, the lack of materials, equipment or resources, and the conservative attitudes of fellow students who did not like taking part in active learning methods.

\title{
Findings and Conclusions
}

The objectives of the study were to assess the major factors that affect the application of active learning methods at some selected Bale Zone secondary schools. For this purpose, a descriptive survey research method was employed. In order to meet the purpose, the following research questions were raised. [1] Does Active learning Methods being employed in Bale zone senor secondary school? [2] What are the major factors hindering the application of Active Learning methods? [3] What are the possibilities to overcome the factors hindering the use of Active Learning methods?

The study involved a total of 509 respondents comprising $(\mathrm{N}=60$ teachers $)$ and $(\mathrm{N}=434$ students $)$ and $(\mathrm{N}=$ 15 different school managers comprising 5 secondary school principals, 5 secondary school unit leaders and 5 secondary school supervisors) from Bale zone. To obtain information from the three groups of respondents, questionnaires and interviews used and observation was employed as data collection instruments. To analysis the data collected from different group respondents, both qualitative and quantitative data analysis methods were used. In this regard, based upon the analysis and interpretations made, the major factors affecting following major findings were found out.

\section{Teachers knowledge of active learning}

Scholars confirmed that the effectiveness of the teaching learning process depends largely on teachers' ability to use interactive method of teaching to help students learn. The Ethiopian government has taken a number of measures particularly aimed at improving the quality of teaching learning. The employment of innovative teaching and learning in the Ethiopian Education \& training Policy of 1994. It was found out in this study that the use of active learning methods was influenced by lack of active learning methods on the part of Teachers' large class size, lack of resource, teacher's 'misconception about active learning methods. Hence, it needs short-term training to improve teacher's perception and knowledge towards active learning methods.

\section{Resource requirement in Bale Zone Senior Secondary School}

As it has presented in literature part of this study availability and quality of teaching materials strongly affect what teacher can do. The application of active learning should not be the sole responsibility of the individual teacher but institutional supports Change in teaching learning method is likely to mean that the institution's resources facility will become more important for the employment of active learning. Teachers are often teaching in a situation where other factors do not influence. The finding of this study shown that lack of institutional support and learning resource were the other factor hindering the implementation of active learning methods at Bale Zone Senior Secondary School.

\section{Active learning and curricular materials in Bale Zone Secondary School}

Curricular materials those actively engage students in process of investigation and discovery have found to be effective in improving students' participation in learning. The current curriculum materials are vast and further overloaded by large content that can be covered by lecture method and not adapted to the local condition to encourage the employment of active learning.

\section{Teachers concern about the employment of student-centered teaching Approach}

It was found out that traditional lecture method, in which teacher talk \&and students listen dominate most 
classroom. This was possibly the result of, teachers' knowledge of active learning limited to only principle than practices and familiarity with lecture than participatory teaching learning

\section{Students view on to be taught by active learning}

Students less preference to actively participate in learning resulted from Socio- cultural influence: traditional view of expecting every think from teacher and regarding teacher as one who know everything.

\section{Conclusions}

The implementation of the Active learning approach in teaching requires different but, inter related human and material resources. Without fulfilment of these essential elements realizing the expected objectives of education is found difficult. In this study, majority of teachers', students, school supervisors' and principals and unit leaders were indicated that the school situations and classroom arrangements were not conductive to implement the active learning approach. Therefore, the situation and classroom arrangements of the schools negatively impact the implementation of Active learning approach in teaching in the selected secondary schools of Bale zone. Therefore, from these groups of respondents it can be arrived at a conclusion that lack of educational resources and pedagogical centers are the major factors that hindering the implementation of Active learning approach in secondary schools of the zone.

\section{Recommendations}

In sum, the findings from the entire investigation revealed that the Active learning approach was not being implemented in most classrooms selected secondary schools Bale zone. Based on the finding, the following Recommendation are forwarded. To tackle the factors impeding the implementation of active learning methods at the schools under study, the following issues needs to be considered:

\section{Employment of partnership approaches:}

On the array running from traditional chalk and talk teaching to open ended instruction, combination of direct instruction, guided practice independent learning in teacher present some amount of materials \& encourage active participation of student is recommended in Ethiopia. In this model, power is shared between learners and teacher for it demands a fruitful collaboration between teacher and students, where each has complementary roles, rather than one being subsidiary to the others.

\section{Modifying curricular materials}

Preparing students for the world of work and lifelong learning involves teaching skills to analyze problems synthesize information and tackle wide range of tasks. Curricular materials therefore should be modified in a way that they involve activities to process the achievable materials, links to the time it requires to achieve, provide opportunity for self-assessment, peer discussion, teachers feedback and other reality checks.

\section{Ensuring the learning resources and school facilities:}

Students become active seekers rather than passive recipients to knowledge when they are provided with necessary learning resource. Employment of active learning requires the meeting of minimum standard of physical infrastructure and other resources. It requires attractive classroom with enough space for making proper seating arrangements suitable for active learning.

\section{Provision of appropriate training to teachers on active learning strategy:}

The evidence from this study indicate that if we want teachers to be confident and innovative users of active learning we must provide teachers with appropriate training, the time and facilities they need. The government has made a good start in demanding teachers to be innovative, but must also continue with empowering teachers with necessary skill they require for proper implementation of interactive teaching and learning.

\section{Emphasizing on continuous assessment}

Failure to periodically solicit student feedback in a course about how its progressing is very important in creating a conducive environment for an active learning approach. Regular, reliable, timely assessment is a key to implementing active learning. The purpose is to give learners feedback and to improve teaching and learning practices. Local circumstances however, prevent the practices from being widely used. Adequate resources, teachers trained in assessment techniques and relatively small class size are required.

\section{Acknowledgement}

I am grateful to all participant of this study for devoting their precious time in filling questioners and involving in interview. I would like to remember all my colleagues for their moral supports.

\section{REFERENCES}

Akmoglu.Orhan and OzkardesRuhan (2007).The Effect of Problem Based Active Learning. Eurasia Journal of Mathematics (3(1); 71-89.

Amare Asgedom.A. (1998).Quality of Education in Ethiopia Vision for the 21st century. Proceeding off national conference: Held in Hawassa. Addis Ababa Institute of Educational Research.A.A.U.

Ar , ., Jacobs, L.C.\&Sorenson, C. (2010).Introduction to research in education. (8th ed.). Belmont: Wadsworth. 
Bransford, J.D., Brown, A.L., and Cocking, R.R. (Eds.) (1999). How people learn: Brain, mind, experience, and school. Washington, D.C.: National Academy Press

Bonwell, C. C., and Eison, J.A. (1991). Active learning: creating excitement in the classroom. ASH\#-ERIC Higher Education Report No. 1, Washington, D.C.: The George Washington University, School of Education and Human Development

Vygotsky, L. S. (1978). Mind in society. Cambridge, MA: Harvard University Press

Best, J.W and Kahn J.V (2002).Research in Education.(7th ed.). New Delhi:Ghosh. Prentice Hall.

Bonwell, C. and Erson, J (1991). Active Learning.Creating Excitements in the Classroom Washington DC: George Washington University.

Caprio, M,W (1994).Easing intoConstructivism. Connecting Meaningfull Learning with Students Experience. Journal of college of teaching

Chickering, A. W. and Gamson, Z. F. (1987).Seven Principles for Good Practice. AAHE Bulletin 39:37.

Chin, Cet al (2002) Student generated questions. A meaning full aspect of learning in scienceInternational Journal of Science Education 24(5

DanialDesta (2004) Observations and Reflection of the high education teachers in Ethiopia. The Ethiopian Journal of Higher Education V,2002

Derebssa ,Dufera(1999). Principles of Curriculum Design \& Development Material for Distance Education.Addis Abeba University: (unpublished)

New York: WLC Books. (Original work published 1916).

Fink, L.D (2003).Creating Significant Learning Experiences. An Integrated Approachto Designing College Courses Sanfransisco: Jurssey Bass.

Firdissa,Jabessa (2005). Active Learning Versus the Traditional Lecture. The EthiopianJournal of Education.

Gardner, H. (2001) 'Jerome S. Bruner' in J. A. Palmer (ed.) Fifty Modern Thinkers on Education. From Piaget to the present, London: Routledge.

Hesson,Mihyar and Shad, Fatima (2007). A Student Centered Learning.Model AmericanJournal of Applied Science 4(9) 628-636. Illich, L. (1971).Deschooling society.Harper and Row.

Loveless, T(1988) The use and misuse of research in educational research. Washington DC. Brooking Institute pres

Martin, F. (2006).Ethno Geography: Future of Primary Geography Conference.Brighton.

Meyers, c. and Jones, T.B. (1993).Promoting Active Learning Strategies for college classroom.Sanfransisco: Jossey-Bass publisher.

Prince M (2004) Does Active Learning Work? A Review of the Research Journal ofEngineering Education 93(3) $223-2$

Standish Alex, (2009) Global Perspectives in the Geography Curriculum. Londonand New York: Taylor and Francis Group

Tashakkon A and Taddlie(1998). Methodology Combining Qualitative and Quantitative approvaches. ThhausandCakes, CA Sage Publications.

Tilbury and Williams ( 2003) Teaching and learning Geography.New York:Taylor andFrancis Guan

Temechegn,Engids (2001) Issues Methods and Materials in Teaching Primary School Subjects.Addis Ababa University.

WOOD D (1998) How Children Think and Learn. (2nd edition) Oxford; Blackwell Publishing.

Woolfolk, Anita E. (1998). Educational Psychology.Seventh Edition. Boston: Allyn and Bacon.

Dr Fazalur Rahman, et al (2011) Relationship between Training of Teachers and Effectiveness Teaching Lecturer, Early Childhood Education \& Elementary Teacher Education Department Allama Iqbal Open University, Islamabad. Vol. 2 No. 4; March 2011 www.ijbssnet.c 